\title{
Pembelajaran Pendidikan Pancasila dan Kewarganegaraan (PPKn) di Daerah Tertinggal
}

\author{
Annisa Hasanah ${ }^{1}$, Junaidi Indrawadi, Maria Montessori \\ Program Magister Pendidikan Pancasila dan Kewarganegaraan Universitas Negeri Padang, Indonesia \\ 1annisa.hasanah01@gmail.com
}

\begin{abstract}
ABSTRAK
Penelitian ini bertujuan untuk mendeskripsikan persiapan dan proses pembelajaran Pendidikan Pancasila dan Kewarganegaraan (PPKn) di daerah tertinggal. Penelitian dilakukan di Sekolah Menengah Pertama Negeri 1 Lahewa Kepulauan Nias Utara. Secara geografis SMPN 1 Lahewa Kepulauan Nias Utara terletak di Kabupaten Kepulauan Nias sebagai salah satu daerah tertinggal sesuai dengan Peraturan Presiden No. 131 Tahun 2015 Tentang Penetapan Daerah Tertinggal 2015-2019. Jenis penelitian ini adalah kualitatif. Data didapat melalui observasi, wawancara, FGD (focus group discussion) dan studi dokumentasi. Dalam penelitian ini data dianalisis dengan metode yang dikemukakan oleh Miles dan Huberman yang memuat tiga alur yaitu kegiatan teknik analisis reduksi data, penyajian data (display data) dan verifikasi data/penarikan kesimpulan. Hasil penelitian menunjukkan tidak adanya persiapan pembelajaran di SMPN 1 Lahewa seperti contohnya guru tidak menyertakan Rencana Pelaksanaan Pembelajaran (RPP) ketika proses belajar mengajar. Fasilitas yang minim serta kurangnya evaluasi administrasi pembelajaran menjadi faktor utama guru lalai dalam mempersiapkan perangkat pembelajaran. Melalui penelitian ini diharapkan perhatian berbagai pihak terutama pemerintah agar memberi perhatian lebih terhadap pelaksanaan pembelajaran, terutama pembelajaran PPKn di daerah tertinggal.
\end{abstract}

Kata kunci: daerah tertinggal, proses pembelajaran, pembelajaran PPKn

\section{ABSTRACT}

This study aims to describe the preparation and learning process of Pancasila and Civic Education (PPKn) in underdeveloped regions. The study was conducted at the public junior high school (SMPN) 1 Lahewa, North Nias Islands. SMPN 1 Lahewa is located in Nias Islands Regency, one of the underdeveloped regions according to Presidential Regulation No. 131 of 2015 about the Determination of Underdeveloped Regions 2015-2019. This research is qualitative. Data was obtained through observation, interviews, FGD (focus group discussions) and documentation studies. The data were analyzed by the method proposed by Miles and Hubermen which contained three channels, namely the activities of data reduction analysis techniques, data presentation (display data) and data verification/drawing conclusions. The results of the study showed that there was no preparation for learning at SMPN 1 Lahewa, for example the teacher did not include the syllabus (RPP) when teaching. The lack of facilities and evaluation of learning administration are the main factors that teachers neglect preparing learning tools. Through this research, it is expected that various parties, particularly the government, pay more attention to the implementation of learning, especially Civic Education in underdeveloped regions.

Keywords: underdeveloped regions, learning process, Civic Education learning 


\section{PENDAHULUAN}

Sebagai mata pelajaran yang memfokuskan pada pembentukan nilai-nilai karakter anak bangsa, PPKn memegang posisi yang cukup strategis dalam membangun karakter bangsa Indonesia. Menurut Nasution (2016), selain untuk menanamkan nilai-nilai karakter, fokus PPKn adalah mendidik generasi muda untuk menjadi warga negara Indonesia yang kritis, aktif, demokratis, dan beradab dalam pengertian generasi muda ini sadar akan hak dan kewajibannya dalam kehidupan bermasyarakat dan bernegara. Sedemikian penting dan urgennya PPKn bagi generasi muda, maka pembelajarannya harus dipersiapkan dengan sedemikian rupa agar tepat sasaran. PPKn sebagai mata pelajaran yang berfokus pada pendidikan karakter memerlukan perencanaan yang matang agar bisa diaplikasikan pada peserta didik dengan baik. Wujud dari sebuah perencanaan pembelajaran adalah rencana pelaksanaan pembelajaran (RPP). Perencanaan akan menentukan apakah pelaksanaan pembelajaran sesuai dengan yang diinginkan atau tidak (Hendra, 2019).

Akan tetapi pelaksanaan pembelajaran PPKn di sekolah masih belum terlaksana dengan maksimal. Hal ini terlihat pada fakta di lapangan bahwa masih banyak guru yang tidak membuat perencanaan pembelajaran dengan baik, ditambah dengan pelaksanaan pembelajaran yang menggunakan metode tidak tepat dan cenderung monoton (Zulfadli, 2016). Selain itu pembelajaran masih dilakukan dengan dominasi guru yang besar dalam proses pembelajaran tanpa berpusat pada siswa (Indrawadi, 2016). Permasalahan pembelajaran di sekolah daerah tertinggal lebih kompleks ketimbang di daerah maju. Ketersedian fasilitas yang sangat minim dan SDM siswa yang rendah membuat proses pembelajaran jauh dari kata baik (Ibrahim, 2019).

Kepulauan Nias adalah salah satu dari sekian banyak daerah-daerah tertinggal di Indonesia yang termasuk dalam kategori Terluar, Tertinggal, Terdepan (3T) sesuai dengan Perpres No. 131 Tahun 2015 tentang Penetapan Daerah Tertinggal 2015-2019. Terletak di sebelah barat pulau Sumatera, Kepulauan Nias secara administratif berada dalam wilayah Sumatera Utara. Aspek ketertinggalan Kepulauan Nias mencakup beberapa sektor salah satunya adalah sektor pendidikan. Tidak idealnya kualitas tenaga pengajar, minimnya sumber belajar mengajar, keterbatasan sarana dan prasarana menjadi potret pendidikan di kepulauan Nias sehingga berada jauh tertinggal dibanding beberapa kabupaten di provinsi Sumatera Utara. Tentu hal ini menjadi momok dan beban mental bagi generasigenerasi muda di Kepulauan Nias terutama yang memiliki semangat belajar tinggi, mereka harus memantapkan diri dalam mengikuti elektabilitas pendidikan.

Ketertinggalan sektor pendidikan di Kepulauan Nias terlihat jelas pada proses pembelajaran PPKn, di mana guru belum sepenuhnya menginternalisasikan nilai-nilai karakter pada siswa sehingga tidak sedikit siswa yang belum memahami arti penting dari mencintai tanah air. Jangankan mencintai tanah air, mencintai budaya sendiri saja masih belum tertanam dalam diri mereka. Padahal Kepulauan Nias merupakan daerah wisata yang sangat populer bagi masyarakat dalam negeri bahkan luar negeri. Hal ini dilihat dari banyaknya wisatawan luar negeri yang berkunjung ke Kepulauan Nias. Hal ini harusnya dapat menjadi kebanggaan bagi 
masyarakat Nias.

Pembelajaran PPKn di sekolah bukan hanya sekedar fokus pada pembahasan materi saja, tetapi tentang cara membentuk mayarakat yang paham serta sanggup menjalankan hak dan kewajiban, sehingga nantinya menjadi seorang warga negara yang berilmu pengetahuan, berbudi pekerti dan berkarakter kebangsaan (Ihsan, 2017). Di samping itu, pembelajaran PPKn juga bertujuan untuk meningkatkan kualitas moral anak bangsa yang belakangan ini seolah memudar (Tuken, 2016). Sebagaimana kita ketahui, Indonesia merupakan negara yang menjunjung tinggi nilai-nilai moral kebangsaan dan mengarahkan setiap warga negara untuk mencintai negaranya. Maka dengan mempelajari PPKn, berarti seseorang akan mengerti bagaimana arti dari mencintai budaya dan tanah air sendiri dalam keanekaragaman di kehidupan sehari-hari (Diana Sari, 2017).

Dengan demikian, untuk meningkatkan kualitas pendidikan dan sumber daya manusia yang berkarakter di Kepulauan Nias, semua komponen masyarakat termasuk guru harus membenahi sistem pembelajaran PPKn di sekolah. Sebab, sekolah merupakan wadah terbaik dalam menanamkan nilai-nilai kebangsaan siswa (Hendra, 2019), namun realita yang ditemukan di lapangan sangat berseberangan dengan apa yang diharapkan. Mata pelajaran PPKn yang seharusnya menjadi dasar bagi pengembangan karakter siswa belum terinternalisasi dengan baik. Sistem pembelajaran masih monoton, guru hanya memiliki buku dari Kemendikbud sebagai sumber belajar, serta kurangnya sarana prasarana dalam proses belajar mengajar dan minimnya kerja sama masyarakat dalam pengembangan mutu pendidikan. Hal tersebut menjadi agenda tersendiri bagi dunia pendidikan di Kepulauan Nias khususnya bagi para guru. Guru mempunyai peran penting dalam dunia pendidikan, yang diharapkan menjadi penuntun terbukanya pikiran dan jiwa kebangsaan siswa, menjadi tauladan serta memberi tauladan, menanamkan nilainilai moral, kebhinekaan, karakter siswa yang sejatinya merupakan fokus pendidikan yang sebenarnya (Kemendikbud, 2017).

\section{METODE PENELITIAN}

Penelitian ini menggunakan pendekatan kualitatif. Penelitian kualitatif merupakan jenis penelitian yang mengedepankan interpretasi data dengan penggambaran secara deskriptif dan analisis secara induktif (Rahmat, 2009). Dalam penelitian kualitatif, peneliti sebagai instrumen harus dapat diterima oleh informan dan lingkungannya agar mampu mengungkap data yang tersembunyi melalui komunikasi dan perilaku dalam dunia dan lingkungan informan.

Penelitian ini menggunakan teknik observasi, wawancara, FGD (focus group discussion) dan studi dokumentasi untuk memperoleh data-data yang berkaitan dengan proses pembelajaran PPKn di SMPN 1 Kepulauan Nias Utara. Observasi dilakukan dengan cara mengamati langsung proses pembelajaran PPKn, lalu mengungkapkan apa saja yang telah dilihat dan dirasa langsung oleh peneliti. Sedangkan wawancara kepada informan dilakukan untuk mengetahui bagaimana proses pembelajaran PPKn. Informan dalam penelitian ini adalah kepala sekolah, guru dan siswa SMPN 1 Lahewa kepulauan Nias Utara. FGD dilakukan untuk mendengarkan saran dan pendapat dari para guru serta melakukan diskusi demi 
mencari penyelesaian masalah yang dihadapi seputar proses pembelajaran PPKn. Studi dokumentasi dilakukan dengan cara pengumpulan data atau dokumendokumen penting sesuai kebutuhan observasi, serta pengumpulan perangkat pembelajaran seperti Rencana Pelaksanaan Pembelajaran (RPP) pada mata pelajaran PPKn di SMPN 1 Lahewa Kepulauan Nias Utara. Dalam penelitian ini data dianalisis dengan metode Miles dan Huberman yang dikutip dari Ahmad Rijali (2018) yang memuat tiga alur yaitu kegiatan teknik analisis reduksi data, penyajian data (display data) dan verifikasi data/penarikan kesimpulan.

\section{HASIL PENELITIAN DAN PEMBAHASAN \\ Perencanaan Pembelajaran}

Mengajar bukan hanya sekedar pencapaian target tetapi sejauh mana seorang guru dan sekolah bisa menghasilkan siswa yang berkualitas sehingga bisa diterima oleh masayarakat dan mampu mempertanggungjawabkan ilmu yang dimiliki (Askhabul Kirom, 2017). Peraturan Pemerintah (PP) Republik Indonesia Nomor 74 Tahun 2008 telah mengatur perihal kompetentensi yang harus dikuasai guru yaitu kompetensi pada segi pedagogik, di mana seorang guru mampu menguasai dan mengelola kegiatan pembelajaran yang menyangkut rencana pembelajaran, pelaksanaan pembelajaran yang bersifat dialogis dan mendidik, serta mengevaluasi hasil pembelajaran tersebut (Indri, 2017). Oleh sebab itu, sebelum melakukan pembelajaran, guru seharusnya membuat rencana atau persiapan pembelajaran agar mencapai tujuan pembelajaran yang diinginkan (Nasution, 2017). Karena perencanaaan juga merupakan langkah awal dari pembelajaran, jadi kedua hal tersebut harus saling melengkapi dan saling mempengaruhi satu sama lain (Saparahayuningsih, 2017). Ada beberapa hal yang mencakup perencanaan pembelajaran, seperti kegiatan analisis Kompetensi Dasar (KD), pengembangan silabus, tujuan pembelajaran, penyediaan RPP, menyediakan bahan ajar lain yang mendukung proses pembelajaran (Gularso, 2017), misalnya pembelajaran dengan menggunakan alat elektronik seperti ponsel untuk mengakses internet, proyektor, dan laptop (Miftah, 2013). Dengan tersedianya perencanaan pembelajaran tersebut, pencapaian tujuan pembelajaran akan lebih terkoordinir dengan baik sesuai yang diharapkan.

Sejatinya setiap guru memiliki persiapan yang matang sebelum melakukan pembelajaran PPKn. Baik dalam hal persiapan sebelum melakukan pembelajaran maupun persiapan lainnya yang menunjang proses pembelajaran. Namun pada saat peneliti melakukan observasi, peneliti menemukan beberapa kejanggalan pada SMPN 1 Lahewa seperti penggunaan bahan ajar yang dimiliki guru PPKn hanya sebatas buku paket siswa Kemendikbud saja, tidak ada buku guru ataupun bahan ajar lainnya. Menurut penuturan guru PPKn di SMP Negeri 1 Lahewa, hal itu disebabkan kurangnya informasi dari kepala sekolah maupun Dinas Pendidikan setempat tentang tata cara penyusunan RPP yang benar, serta kurangnya sarana dan prasarana sekolah guna menunjang metode pembelajaran yang lebih signifikan lagi. Kurangnya sosialisasi kepala sekolah dan jarangnya MGMP (Musyawarah Guru Mata Pelajaran) yang harusnya dipromotori oleh Dinas Pendidikan setempat menjadi momok tersendiri bagi perkembangan sistem belajar guru khususnya di SMP Negeri 1 Lahewa. Dengan kata lain, terlihat masih kurangnya koordinasi antara kepala sekolah dengan para staf pengajar serta minimnya komunikasi antara guru 
dan siswa. Padahal di samping pengelolaan kelas, pengelolaan sekolah juga diperlukan untuk memperkuat manajemen organisasi pada sekolah tersebut, dengan peran kepala sekolah sebagai pemimpin yang memberi perhatian dalam berbagai aspek seperti aspek informal dan simbolis kepada warga sekolah (Yuliana, 2016).

Permasalahan di atas adalah beberapa penyebab guru kurang memahami pentingnya membuat persiapan proses pembelajaran seperti menyediakan RPP dan bahan ajar lainnya. Faktanya, RPP tidak dipergunakan ketika guru melakukan pembelajaran di kelas walaupun sebenarnya setiap guru mengetahui bahwa perangkat pembelajaran wajib disiapkan oleh guru sebelum melakukan pembelajaran. Namun di SMPN 1 Lahewa yang peneliti datangi, tiga dari guru mata pelajaran PPKn tidak menyediakan perangkat pembelajaran saat mengajar. Ketika peneliti menanyakan, guru-guru PPKn tidak membuat perangkat pembelajaran karena sekolah tidak terlalu memprioritaskan RPP, silabus dan perangkat lainnya dan hanya diingatkan pada awal semester saja oleh kepala sekolah.

Dengan demikian kompetensi yang akan dicapai menjadi tidak terarah karena aktivitas pembelajaran yang dilakukan siswa tidak sepenuhnya terlaksana. Seharusnya guru perlu menyiapkan aktivitas penunjang yang lengkap dan jelas sehingga kompetensi yang diinginkan bisa mencapai target perencanaan yang lebih terarah dan efisien (Utami, 2013).

\section{Proses Pembelajaran}

Proses pembelajaran pada jenjang SMP sebaiknya menerapkan metodemetode yang berbeda dengan pembelajaran di sekolah dasar yang biasanya hanya berpikir secara kongkrit, maka siswa di SMP bisa mengembangkan proses pembelajaran dengan membiasakan pemikiran-pemikiran yang abstrak dan logis (Yuniwati \& Siasah, 2016). Terkait pelaksanaan pembelajaran, mata pelajaran PPKn masih dianggap sebagai mata pelajaran yang membosankan. Hal ini ditandai dengan tidak pedulinya guru mata pelajaran kepada perangkat pembelajaran di mana guru hanya masuk kelas dengan membawa buku dari kemendikbud saja tanpa menyiapkan bahan ajar lainnya sehingga tuntutan kurikulum 2013 yang mengutamakan pembelajaran saintifik tidak berjalan dengan efisien. Hampir setiap jam pembelajaran PPKn guru selalu menggunakan metode ceramah. Sesekali guru membuat metode diskusi namun belum mengarah pada tujuan pembelajaran yang diharapkan karena bahan yang digunakan hanya sebatas buku siswa, otomatis sumber belajar masih sangat minim dan tidak cukup untuk memunuhi standar belajar. Hal inilah yang menyebabkan pembelajaran PPKn di SMPN 1 Lahewa menjadi monoton sehingga membuat siswa merasa bosan sewaktu belajar.

Berdasarkan observasi peneliti, terlihat guru masuk kelas dan langsung memberikan kegiatan latihan yang ada di buku siswa lalu beranjak dari ruangan kelas tanpa ada kegiatan pembuka, kegiatan inti dan penutup. Saat peneliti mengkonfirmasikan dengan salah satu siswa, proses seperti ini memang kerap terjadi. Menurut penuturan siswa tersebut, sering juga guru masuk kelas dan langsung memerintahkan bentuk kelompok untuk menjawab soal yang ada di buku siswa. Begitulah fakta pembelajaran PPKn di SMPN 1 Lahewa Kepulauan Nias Utara.

Urgensi tugas guru terlihat jelas dari permasalahan di atas. Sumber belajar 
merupakan faktor yang sangat krusial tetapi sekolah tidak memfasilitasinya, sehingga gurulah yang menjadi sumber belajar yang paling dominan yang kemudian diharapkan memecahkan masalah tersebut dengan pihak terkait seperti kepala sekolah dan dinas pendidikan setempat. Guru hanya menerima apa adanya keadaan sekolah sehingga siswa menjadi korban ketidakstabilan proses belajar mengajar. Pada dasarnya sumber belajar memberikan bermacam keuntungan bagi siswa, seperti: (1) mendorong siswa untuk meyakini bahwa dalam dirinya ada bakat yang selama ini belum pernah diasah, (2) pembelajaran menjadi menyenangkan dan menimbulkan efek ketagihan bagi siswa, (3) pembelajaran siswa lebih terarah baik dari segi waktu, dan tujuan pencapaian yang jelas (Supriadi, 2015). Namun untuk menginternalisasikannya, sebelum memulai proses pembelajaran guru harus memiliki perencanaan dan persiapan yang benar-benar matang. Persiapan yang dimaksud adalah setiap guru harus mempunyai RPP yang mana di dalamnya memuat langkah-langkah proses pembelajaran, dimulai dari alolasi waktu, kegiatan pembuka, kegiatan inti hingga penutup (Permendikbud No 22 : 2016).

Pada saat kegiatan pembuka, sebelum memulai pembelajaran guru tidak mengajak siswa menyanyikan salah satu lagu wajib nasional sesuai dengan rencana pembelajaran, namun guru memotivasi siswa untuk berperilaku peduli sebagai wujud pelaksanaan semangat. Sebagai kegiatan inti, guru memulai pembelajaran dengan cara membentuk kelompok untuk mengerjakan latihan yang tertera di buku paket siswa. Kemudian pada kegiatan penutup, guru mengumpulkan soal per kelompok, dan mengajak siswa mengucap syukur di akhir pembelajaran.

\section{Evaluasi Pembelajaran}

Dalam pelaksanaan evaluasi pembelajaran, guru sebaiknya mengkondisikannya sesuai dengan prosedur, memperhatikan keterbatasan waktu serta memahami betul perbedaan siswa dari segi pemahaman dan perilaku (Ruslan \& Saiful, 2016). Pada tahap ini guru bisa mengetahui sejauh mana siswa memahami pelajaran dan seberapa berhasil guru dalam mengajar. Sebagaimana pemaparan Nurkancana (1983) bahwa fungsi evaluasi pendidikan adalah untuk mencari tahu kesediaan siswa dalam mengikuti proses pembelajaran dan hasil pembelajaran yang telah diberikan guru, menjadi referensi guru dalam mengkonsultasikan prospek ke depan siswa sesuai dengan kemampuan akademik dan keterampilan yang ia miliki, mempermudah guru mengambil keputusan kenaikan kelas siswa, dan mengetahui bakat yang dimiliki masing-masing siswa. Dari pemaparan tersebut dapat disimpulkan bahwa evaluasi pembelajaran bukan saja dilihat dari segi kognitif saja, namun harus memperhatikan afektif dan psikomotorik juga.

Hasil observasi yang peneliti lakukan di SMP Negeri 1 Lahewa menunjukkan bahwa hasil evaluasi hanya berupa penilaian bentuk deskriptif dalam bentuk ulangan harian yang diarsipkan oleh guru tanpa membagi hasil ulangan kepada siswa. Dalam penilaian hasil evaluasi yang guru lakukan belum terlihat evaluasi dari segi penilaian sikap dan karakter masing-masing siswa. Dalam artian penilaian yang dilakukan masih bersifat kognitif dan mengabaikan aspek afektif. Sejatinya PPKn yang berorientasi pada pembentukan karakter, maka penilaian afektif harusnya mendapatkan porsi lebih dalam evaluasi sehingga tujuan pendidikan 
Indonesia dalam membentuk manusia Indonesia yang berkarakter dapat tercapai. Peta konsep evaluasi pembelajaran yang terjadi di daerah tertinggal diilustrasikan dengan Gambar 1.

\section{Gambar 1. Peta Konsep Evaluasi Pembelajaran yang Terjadi di Daerah Tertinggal}

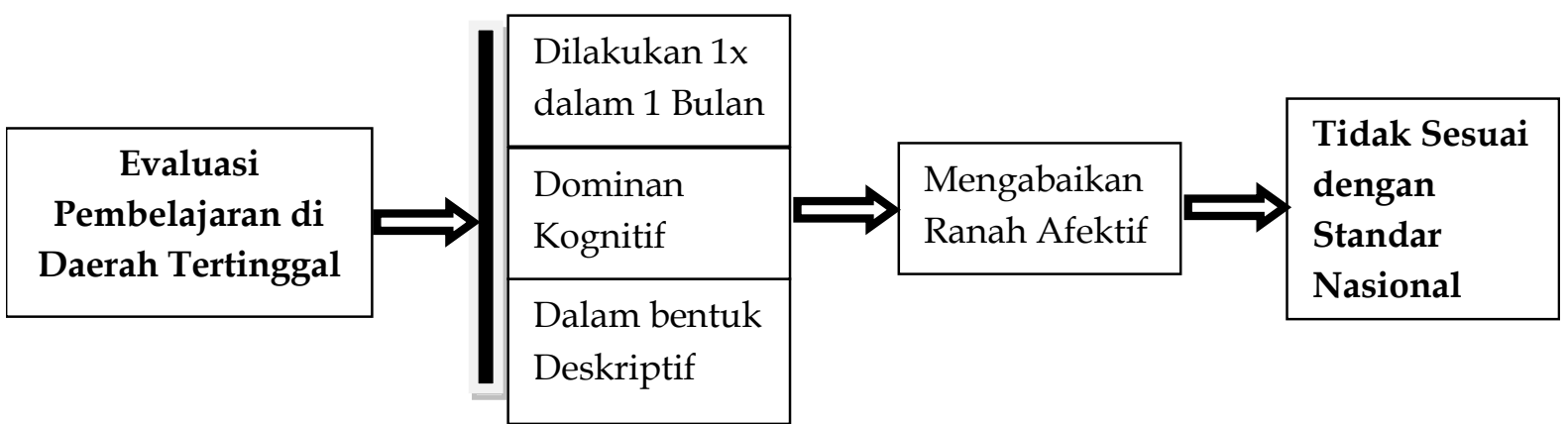

Sumber: Observasi Lapangan 8 Agustus 2019

\section{SIMPULAN}

Berdasarkan pembahasan di atas, maka dapat disimpulkan bahwa pada pembelajaran PPKn di daerah tertinggal, guru masih sangat jauh di bawah standar nasional pendidikan Indonesia. Pada perencanaan pembelajaran, guru masih belum memiliki RPP yang akan digunakan sebagai pedoman melaksanakan pembelajaran. Pada proses pembelajaran, guru masih cenderung monoton dan tidak mampu mengembangkan proses pembelajaran yang lebih menarik karena keterbatasan sumber belajar dan kurangnya sosialisasi tentang penggunaan media yang menyenangkan. Sedangkan dalam evaluasi pembelajaran, guru mengabaikan evaluasi menyeluruh perkembangan siswa, sehingga lebih dominan ke ranah kognitif dibandingkan afektif. Artikel ini menggambarkan pelaksanaan pembelajaran PPKn di daerah tertinggal dengan harapan agar pemerintah lebih memperhatikan keadaan pendidikan di daerah tertinggal yang jumlahnya cukup signifikan di Indonesia. Perhatian yang dimaksudkan tidak hanya berupa pengadaan fasilitas belajar yang masih minim, namun juga pemberdayaan guru melalui berbagai kegiatan seperti seminar atau pelatihan kompetensi guru dalam mengelola kelas dan membuat perencanaan pembelajaran. Dengan demikian pembelajaran pada umumnya, terkhusus pembelajaran PPKn di daerah tertinggal bisa berjalan dengan maksimal demi tercapainya tujuan pendidikan nasional. Penelitian selanjutnya dapat menganalisis model perkembangan pembelajaran yang cocok untuk daerah tertinggal di Indonesia.

\section{REFERENSI}

Ahmad Rijali. (2018). Analisis Data Kualitatif. Jurnal Alhadharah, 17 (33), 81-95.

Askhabul Kirom. (2017). Peran Guru dan Peserta Dididk Dalam Proses Pembelajaran Berbasis Multikultural. Jurnal Pendidikan Agama Islam, 3 (1), 69-80.

Diana Sari. (2017). Cinta Tanah Air dan Salafus Shalih. Prosiding Konferensi Nasional Kewarganegaraan, p-ISSN 259, 64-72.

Gularso. (2017). Analisis kesulitan dalam perencanaan pembelajaran tematik di sekolah dasar. Jurnal Pendidikan Sekolah Dasar, 3 (1), 63-73. 
Hendra. (2019). Internalisasi Nilai Religius dalam Pembelajaran Pendidikan Pancasila dan Kewarganegaraan di Sekolah Daerah Tertinggal. Jurnal Pendidikan Ilmu-Ilmu Sosial Education, 11 (1), 84-94.

Ibrahim, dkk. (2019). Pembelajaran Sejarah pada SMAN di Daerah Terdepan, Terluar, Tertinggal (3T) Kepulauan Tanimbar Provinsi Maluku. Jurnal Pendidikan Sejarah, 8 (1), 35-49.

Ihsan. (2017). Kecenderungan Global Dalam Proses Pembelajaran Pendidikan Pancasila Dan Kewarganegaraan di Sekolah. Jurnal Pancasila Dan Kewarganegaraan, 2 (2), 49-59.

Indrawadi, J. (2016). Pendidikan dan Kompetensi Guru dalam Pembangunan Peradaban Bangsa (Analisis Penanaman Nilai-nilai Karakter oleh Guru Pada Sekolah Dasar Pesisir Pantai Kota Padang). Konvensi Nasional Pendidikan Indonesia (KONASPI) VIII.

Indri. (2017). Analisa Faktor-Faktor yang Mempengaruhi Proses Belajar Guru-Guru Sekolah Dasar. Jurnal Manajemen Pendidikan, 4 (2), 205-212.

Kemendikbud. (2017). Gerakan Penguatan Pendidikan Karakter (PPK).

Miftah. (2013). Fungsi dan Peran Media Pembelajaran Sebagai Upaya Peningkatan Kemampuan Belajar Siswa. Jurnal Kwangsan, 1 (2), 95-105.

Mulyadi. (2013). Penelitian Kuantitatif Dan Kualitatif Serta Pemikiran Dasar Menggabungkannya. Jurnal Studi Komunikasi Dan Media, 15 (1), 127-138. https:// doi.org/10.31445/jskm.2011.150106

Nasution. (2017). Penggunaan Metode Pembelajaran Dalam Peningkatan Hasil Belajar Siswa. Jurnal Ilmiah Bidang Pendidikan, 11 (1), 9-16.

Nasution, A.R., (2016), Urgensi Pendidikan Kewarganegaraan sebagai Pendidikan Karakter Bangsa Indonesia melalui Demokrasi, HAM dan Masyarakat Madani, Jurnal Pendidikan Ilmu-Ilmu Sosial, 8 (2) (2016): 201212

Nurkancana, Wayan dan P.P.N. Sumartana. (1986). Evaluasi Pendidikan. Surabaya: Usaha Nasional.

Permendikbud No 22: 2016. (n.d.), 1-15.

Rahmat. (2009). Penelitian Kualitatif. Journal Equilibrium, 5 (9), 1-8. Retrieved from yusuf.staff.ub.ac.id/files/2012/11/Jurnal-Penelitian-Kualitatif.pdf

Ruslan \& Saiful. (2016). Proses Penilaian Guru PPKn di SMP Se-Kecamatan Syamtalira Aron. Jurnal Ilmiah Maahasiswa Pendidikan Unsyiah, 1 (1), 31-42.

Saparahayuningsih, D. (2017). Perencanaan Pembelajaran Kurikulum 2013 Pendidikan Anak Usia Dini. Jurnal Potensia, 2 (1), 1-13.

Supriadi. (2015). Pemanfaatan Sumber Belajar Dalam Proses Pembelajaran. Lantanida Journal, 3 (2), 128-139.

Tuken. (2016). Peningkatan Hasil Belajar Siswa Pada Mata Pembelajaran PPKn. Jurnal Publikasi Pendidikan, VI (2), 123-129.

Widya Utami. (2013). Analisis Kesesuaian Langkah- langkah Pembelajaran Padaa Rencana Pelaksanaan Pembelajaran Pembelajaran Guru Mata Pelajaran Dengan Pendekatan Saintifik di SMA Yang Telah Menerapkan Kurikulum 2013. Jurnal Pembelajaran Biologi, 2 (1), 83-95.

Yuliana. (2016). Manajemen Sekolah Untuk Mencapai Sekolah Unggul Yang 
Menyenangkan. Jurnal Pendidikan Dan Kebudayaan, 1 (2), 203-217.

Yuniwati \& Siasah. (2016). Peningkatan Kualitas Pembelajaran PPKn Melalui Penerapan Problem Based Learning di SMP. Jurnal Pendidikan IPS, 3 (2), 199210.

Zulfadli. (2016). Permasalahan dan Solusi Pendidikan di Daerah Kepulauan. Jurnal Pencerahan, 10 (1) (September), 48-61. 